\title{
Adsorption of reactive yellow BF-3R dye by CTABr modified zeolite NaY
}

\author{
Adsorção do corante amarelo BF-3R reativo por zeólita NaY modificada com CTABr \\ Adsorción de colorante amarillo BF-3R reactivo por zeolita $\mathrm{NaY}$ modificada con $\mathrm{CTABr}$
}

Received: 10/22/2021 | Reviewed: 10/30/2021 | Accept: 11/01/2021| Published: 11/03/2021

\author{
Thiago Rodrigo Barbosa Barros \\ ORCID: https://orcid.org/0000-0002-0857-2017 \\ Universidade Federal de Campina Grande, Brazil \\ E-mail: thiagojdbarbosa@gmail.com \\ Thianne Silva Batista Barbosa \\ ORCID: https://orcid.org/0000-0002-1828-8546 \\ Universidade Federal de Campina Grande, Brazil \\ E-mail: thianne.siilva@gmail.com \\ Meiry Gláucia Freire Rodrigues \\ ORCID: https://orcid.org/0000-0003-2258-4230 \\ Universidade Federal de Campina Grande, Brazil \\ E-mail: meiry.rodrigues@ufcg.edu.br
}

\begin{abstract}
Textile industries generate effluents composed of organic salts and complexes from dyes not fixed on fabrics, or not degraded by the inefficiency of conventional treatment processes, which represents a high potential for environmental impact due to inadequate disposal of the generated effluent. Zeolites are porous materials that have a three-dimensional structure containing tetrahedrals of $\mathrm{AlO} 4 \mathrm{e} \mathrm{SiO} 4$ which can be modified to improve its properties. The adsorption process using zeolites as adsorbents can be considered an excellent economic physical treatment to solve or minimize such a problem. This work presents an experimental study focusing on the preparation and characterization of zeolite NaY and modified with organic surfactant cetyltrimethylammonium bromide (CTABr) intended to be used as adsorbent in the process of removing yellow dye BF-3R in dye-water system batch system. The samples were characterized by $\mathrm{X}$-ray diffraction (XRD), Infrared spectroscopy (IR) and thermogravimetry (TG). The effect of process parameter such as $\mathrm{pH}$ was studied. Results revealed that even though the modified cetyltrimethylammonium bromide organic surfactant $(\mathrm{CTABr})$ did not cause alterations on the zeolite NaY structure. The IR results revealed that CTABr was successfully incorporated to zeolite $\mathrm{NaY}$ structure. The best conditions were established with respect to $\mathrm{pH}$ to saturate the available sites located on the zeolite $\mathrm{NaY}$ and NaY_CTABr surface. The maximum adsorption capacities were $3.35 \mathrm{and} \mathrm{mg} / \mathrm{g}$ for dye 5.35 using as-synthesized zeolite $\mathrm{NaY}$ and $\mathrm{CTABr}$ modified zeolite NaY. Modified zeolites are excellent adsorbents for removing reactive dyes from industrial wastewater.
\end{abstract}

Keyword: Zeolite Y; Surfactant modified zeolite; Adsorption; Yellow dye BF-3R; Dyes removal.

\section{Resumo}

As indústrias têxteis geram efluentes compostos por sais orgânicos e complexos a partir de tintas não fixadas nos tecidos, ou não degradadas pela ineficiência dos processos convencionais de tratamento, o que representa um alto potencial de impacto ambiental devido ao descarte inadequado do efluente gerado. Zeólitas são materiais porosos que possuem uma estrutura tridimensional contendo tetraédricos de $\mathrm{AlO} 4$ e $\mathrm{SiO} 4$ que podem ser modificados para melhorar suas propriedades. O processo de adsorção utilizando zeólitas sintéticas e modificadas como adsorventes pode ser considerado um excelente tratamento físico econômico para solucionar ou minimizar tal problema. Este trabalho apresenta um estudo experimental com foco na preparação e caracterização da zeólita $\mathrm{NaY}$ e modificada com surfactante orgânico brometo de cetiltrimetilamônio (CTABr) destinado a ser utilizado como adsorvente no processo de remoção do corante amarelo BF3R em sistema batelada sistema corante-água. As amostras foram caracterizadas por difração de raios X (XRD), espectroscopia de infravermelho (IV) e termogravimetria (TG). O efeito do parâmetro do processo, como o pH, foi estudado. Os resultados revelaram que o surfactante orgânico brometo de cetiltrimetilamônio modificado (CTABr) não causou alterações na estrutura dao zeólita $\mathrm{NaY}$. Os resultados de IV revelaram que o CTABr foi incorporado com sucesso à estrutura da zeólita $\mathrm{NaY}$. As melhores condições foram estabelecidas com relação ao pH para saturar os sítios disponíveis localizados na superfície da zeólita NaY e NaY_CTABr. As capacidades máximas de adsorção foram 3,35 e mg/g para o corante 5,35 usando zeólita NaY como sintetizada e zeólita NaY modificada por CTABr. As zeólitas modificadas são excelentes adsorventes para a remoção de corantes reativos de águas residuais industriais.

Palavras-chave: Zeólita Y; Zeólita Y modificada com surfactante; Adsorção; Corante amarelo BF-3R; Remoção de corantes. 


\begin{abstract}
Resumen
Las industrias textiles generan efluentes compuestos por sales orgánicas y complejos a partir de tintes no fijados en los tejidos, o no degradados por la ineficiencia de los procesos de tratamiento convencionales, lo que representa un alto potencial de impacto ambiental por disposición inadecuada del efluente generado. Las zeolitas son materiales porosos que tienen una estructura tridimensional que contienen tetraédricos de $\mathrm{AlO} 4$ y SiO4 que pueden modificarse para mejorar sus propiedades. El proceso de adsorción que utiliza zeolitas sintéticas y modificadas como adsorbentes puede considerarse un excelente tratamiento físico económico para resolver o minimizar dicho problema. En este trabajo se presenta un estudio experimental centrado en la preparación y caracterización de zeolita NaY y modificada con tensoactivo orgánico bromuro de cetiltrimetilamonio (CTABr) destinado a ser utilizado como adsorbente en el proceso de remoción del tinte amarillo BF-3R en el sistema por lotes del sistema colorante-agua. Las muestras se caracterizaron por difracción de rayos X (XRD), espectroscopia infrarroja (IR) y termogravimetría (TG). Se estudió el efecto de parámetros del proceso como el $\mathrm{pH}$. Los resultados revelaron que aunque el tensioactivo orgánico de bromuro de cetiltrimetilamonio modificado (CTABr) no provocó alteraciones en la estructura de la zeolita NaY. Los resultados de IR revelaron que CTABr se incorporó con éxito a la estructura de la zeolita $\mathrm{NaY}$. Se establecieron las mejores condiciones con respecto al pH para saturar los sitios disponibles ubicados en la superficie de la zeolita NaY y NaY_CTABr. Las capacidades máximas de adsorción fueron $3.35 \mathrm{y} \mathrm{mg} / \mathrm{g}$ para el tinte 5.35 usando zeolita NaY sintetizada y zeolita NaY modificada con CTABr. Las zeolitas modificadas son excelentes adsorbentes para eliminar los tintes reactivos de las aguas residuales industriales.
\end{abstract}

Palabras clave: Zeolita Y; Zeolita Y modificada con tensioactivo; Adsorción; Eliminación de tinte.

\title{
1. Introduction
}

With the advance of industrial production, dyes have been widely applied in various sectors, such as: textiles, inks, pharmaceuticals, cosmetics, plastics, paper, etc. (Radoor et al., 2021). The textile sector is considered one of the largest industrial water consumers in the world, being also responsible for inappropriately disposing of large amounts of effluents in water bodies and, thus, leading to the decline of ecosystem biodiversity, due to its high concentrations, strong toxicity, and low biodegradability (Radoor et al.; 2020; Ma et al., 2020).

Dyes are a major contributor to water source pollution, and textile industries worldwide are reported to be the main sources of dye effluent disposal (Nupearachchi et al., 2017; Wanyonyi et al., 2014). There are more than 100.000 commercially available dyes with more than $7 \times 10^{5}$ tons of dyes produced annually (Jose et al., 2018). These materials have complex aromatic structures and exhibit great structural diversity, their properties are enhanced to resist fade, improve tissue distribution, and have a variety of shades, which makes them highly resistant to degradation (Kabra et al., 2011).

These organic compounds have three essential groups in their molecules: the chromophore, the autochrome and the matrix (Laurent et al., 2010). The chromophore is the active site of the dye and can summarize the spatial location of the atoms that absorb light energy, the most common groups of atoms in chromophores are nitro $\left(-\mathrm{NO}_{2}\right)$, azo $(-\mathrm{N}=\mathrm{N}-)$, nitrous $(-\mathrm{N}=\mathrm{O})$, thiocarbonyl $(-$ $\mathrm{C}=\mathrm{S}$ ), carbonyl $(-\mathrm{C}=\mathrm{O})$, as well as the alkenes $(-\mathrm{C}=\mathrm{C}-$ ) (Azzopardi et al., 2017; Benkhaya, Rabet, \& Harfi, 2020). Reactive dyes are the most used because of their favorable characteristics of brilliant color, water resistance, simple application techniques and low energy consumption. Because they have different chemical structures, they are not easily biodegradable, therefore, even after extensive treatments, the color can remain in the effluent (Ahmad, \& Rahman, 2011).

Adsorption is a physicochemical treatment method, in which an adsorbent material will remove specific molecules (adsorbate) from a liquid medium by physisorption and chemosorption interactions, which depends on several factors, such as: temperature, pressure, concentration of the medium reaction, physical and chemical characteristics of the adsorbent, as well as the surface area of it (Cooney, 1999; Ruthven, 1984; Ngulube et al., 2017). Different effective and low-cost adsorbents for dye removal were synthesized by different researchers, such as clay, magnetic nanoparticles, agricultural residues, and zeolites (Radoor et al., 2021; Sivalingam, \& Sen, 2018).

Zeolites are hydrated microporous crystalline aluminosilicates with alternating tetrahedral units of $\mathrm{SiO}_{4}$ and $\mathrm{AlO}_{4}$ that are covalently joined by oxygen atoms to form well-defined structures, large surface area, wide channels, pore diameter with larger openings, in addition to exhibiting a large capacity for adsorption with good cation exchange properties (Johnson, \& Arshad, 2014; 
Lo et al., 2018). These materials have a negative charge due to isomorphic substitution by $\mathrm{Al}$ atoms in some $\mathrm{Si}$ places in their structure, which must be compensated by other cations, mainly from the 1A and 2A families (Khaleque et al., 2020).

To improve the properties of zeolites and obtain better adsorption efficiency in removing dyes, these materials must be modified. One of the methods of modification is the use of surfactants that are structurally composed with a small positive hydrophilic head that results in the occupation of only one site and has a hydrophobic hydrocarbon tail which helps to adsorb organic molecules in aqueous solution. (Zagho et al., 2021). The best-known cationic surfactants, used due to their efficiency in modifying porous materials, are cetyltrimethylammonium bromide, chloride, or hydroxide (CTABR, CTACL e CTAOH, respectively), mainly due to the low cost of these reagents (Martins et al., 2021).

Our research group has published some papers on the production of adsorbents and membranes for separation dyes (Barbosa et al., 2019; Barbosa et al., 2015; Barbosa, Rodrigues, \& Rodrigues, 2019; Barbosa, Rodrigues, \& Rodrigues, 2019; Lima et al., 2014; Lima, Paula, \& Rodrigues, 2014; Nogueira et al., 2020; Oliveira et al., 2020; Paula, Paula, \& Rodrigues, 2020; Rocha, Barbosa, \& Rodrigues, 2016; Rocha, Barbosa, \& Rodrigues, 2016; Rocha et al., 2017; Rocha et al., 2017; Rocha et al., 2015; Rodrigues, Barbosa, \& Rodrigues, 2020; Rodrigues, Barbosa, \& Rodrigues, 2020; Silva et al., 2019; Silva et al., 2019; Silva et al., 2019; Silva et al., 2019; Silva et al., 2020; Silva et al., 2020; Tomaz et al., 2019).

This work aims to examine the adsorption capacities of as-synthesized zeolite $\mathrm{NaY}$ and $\mathrm{CTABr}$ modified zeolite $\mathrm{NaY}$ for the sorption of reactive yellow dye BF-3R from aqueous solutions. The adsorption of reactive yellow dye BF-3R onto zeolite was studied by performing batch kinetic experiments. The effect of parameter such as $\mathrm{pH}$ was analyzed for the purpose of understanding the adsorption behavior of dye onto zeolites.

\section{Methodology}

This work was carried out at the Laboratório de Desenvolvimento de Novos Materiais (LABNOV), belonging to the Unidade Acadêmica de Engenharia Química, located at the Centro de Ciências e Tecnologia of the Universidade Federal de Campina Grande (UAEQ/CCT/UFCG).

\subsection{Materials and Chemical}

Deionized water, Sodium Aluminate $\left(\mathrm{NaAlO}_{2}\right)$, Sodium Silicate $\left(\mathrm{Na}_{2} \mathrm{SiO}_{3}\right)$, Sodium Hydroxide $(\mathrm{NaOH})$, Cetyltrimethylammonium Bromide $\left(\mathrm{C}_{19} \mathrm{H}_{42} \mathrm{NBr}\right)$ were purchased from Sigma-Aldrich (Merck).

Reactive Yellow BF-3R was supplied by Texpal Quím., São Paulo, Brazil. BF-5G is bifunctional dye, which is composed of a system of chromophores, linked to two reactive systems: a vinyl sulfone group and another chlorine triazine group. The main properties of Reactive Yellow BF-3R dye are summarized in Table 1.

Table 1. Properties of reactive yellow BF-3R dye.

\begin{tabular}{|c|c|c|c|c|}
\hline Name & Dye & Molecular formula & CAS & Molecular mass (g.mol $^{\mathbf{1}}$ ) \\
\hline Reactive Yellow BF-3R dye & Reactive Yellon 145 & $\mathrm{C}_{28} \mathrm{H}_{20} \mathrm{ClN}_{9} \mathrm{Na}_{4} \mathrm{O}_{16} \mathrm{~S}_{5}$ & $93050-80-7$ & 1024.89 \\
\hline
\end{tabular}

Source: Authors.

\subsection{Synthesis of the Zeolite NaY}

A zeolite was synthesized according to the procedure reported in the literature (IZA (International Zeolite Association). 


\section{Synthesis Gel (A)}

The sodium hydroxide $(\mathrm{NaOH}-4.07 \mathrm{~g})$ was dissolved in deionized water $\left(\mathrm{H}_{2} \mathrm{O}-19.95 \mathrm{~g}\right)$ and the sodium aluminate $\left(\mathrm{NaAlO}_{2}-2.09 \mathrm{~g}\right)$ was slowly added under constant stirring until total dissolution (solution 1). Then, $8.55 \mathrm{~g}$ of sodium silicate $\left(\mathrm{Na}_{2} \mathrm{SiO}_{3}\right)$ and $14.25 \mathrm{~g}$ of deionized water were added to the solution (1) and left under stirring for a period of $24 \mathrm{~h}$ at room temperature (synthesis gel A).

\section{Synthesis Gel (B)}

After a period of 24 hours, another gel was prepared through the following steps: in a beaker, sodium hydroxide $(\mathrm{NaOH}-$ $0.04 \mathrm{~g})$ was dissolved in deionized water $\left(\mathrm{H}_{2} \mathrm{O}-32.85 \mathrm{~g}\right)$ and then $3.28 \mathrm{~g}$ of aluminate was added, sodium, stirred until homogeneous, (solution 2). Then, $22.24 \mathrm{~g}$ of deionized water and $13.39 \mathrm{~g}$ of sodium silicate were added to solution (2), stirred in a beaker until dissolved (gel B). After the synthesis gel preparation process, $4.16 \mathrm{~g}$ of the gel (A) were mixed with the gel (B) and left under stirring for a period of $20 \mathrm{~min}$. Then it placed in a stainless steel autoclave where the hydrothermal synthesis occurred at $90{ }^{\circ} \mathrm{C}$ for $7 \mathrm{~h}$. The molar composition of the reaction mixture was $4.6 \mathrm{Na}_{2} \mathrm{O}: \mathrm{Al}_{2} \mathrm{O}_{3}: 10 \mathrm{SiO}_{2}: 180 \mathrm{H}_{2} \mathrm{O}$.

After the hydrothermal treatment was completed, the autoclave was removed from the oven and cooled to room temperature. Subsequently, the sample was washed with distilled water until $\mathrm{pH} 9$ and dried in overnight at $60^{\circ} \mathrm{C}$.

Figure 1 show the flow diagram synthesis of zeolite $\mathrm{NaY}$.

Figure 1. Flow diagram synthesis of zeolite $\mathrm{NaY}$.

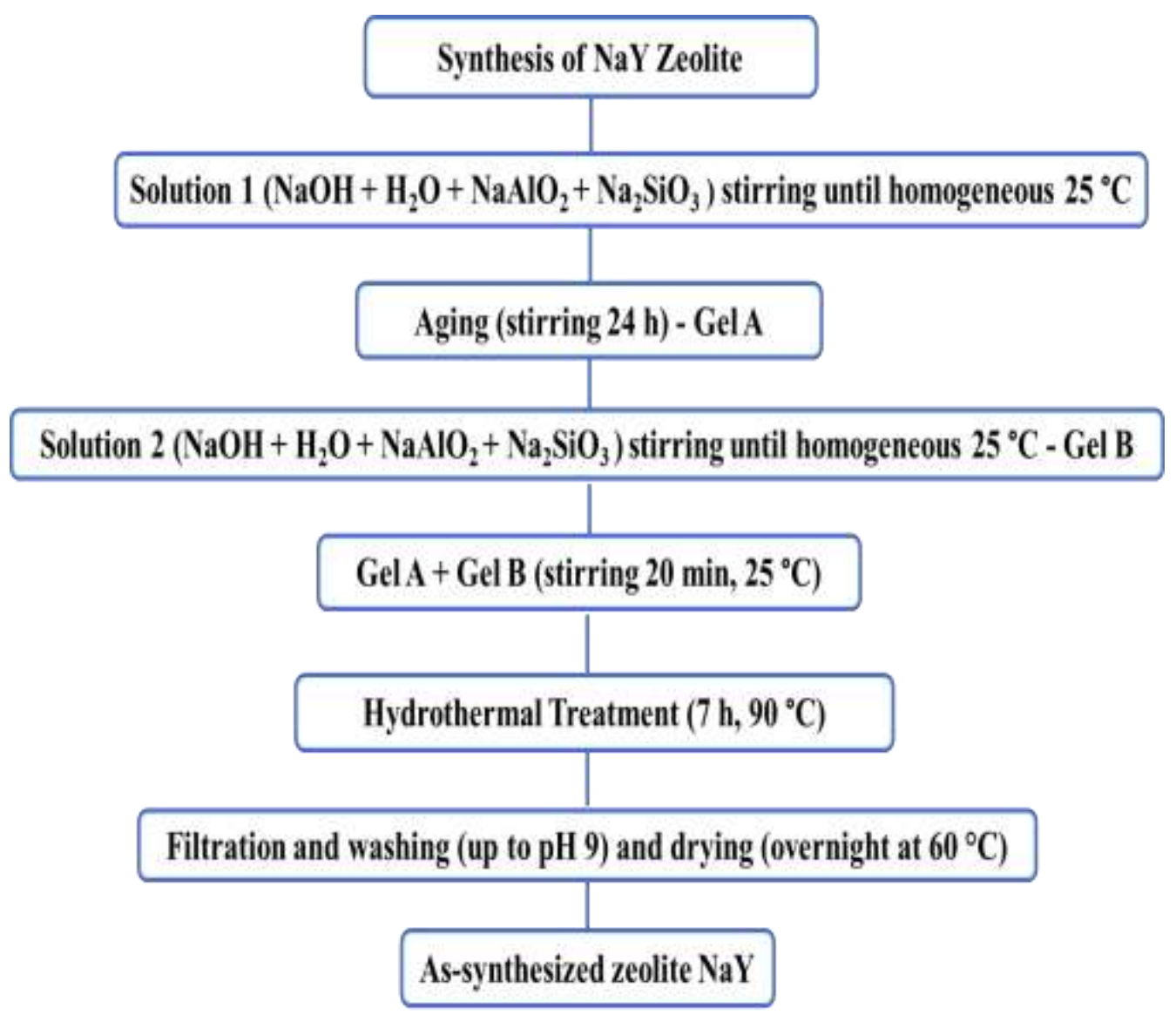

Source: Authors. 


\subsection{Modification of the zeolite NaY}

The cation exchange capacity of zeolite $\mathrm{Y}$ is $2.5 \mathrm{meq} / \mathrm{g}$ (Hashemi et al., 2019). Modification of the zeolite NaY, according to the procedure described by authors (Shinzato, 2008), considering an ion exchange percentage of $100 \%$, a mixture of $2.0 \mathrm{~g}$ of zeolite $\mathrm{NaY}$ with a solution of $100 \mathrm{~mL}$ of CTABr $0.1 \mathrm{M}$ was carried out using a magnetic stirrer at room temperature for $24 \mathrm{~h}$.

Figure 2 show the flow diagram of the modification of zeolite $\mathrm{NaY}$ with $\mathrm{CTABr}$.

Figure 2. Flow diagram of the $\mathrm{CTABr}$ modified zeolite $\mathrm{NaY}$.

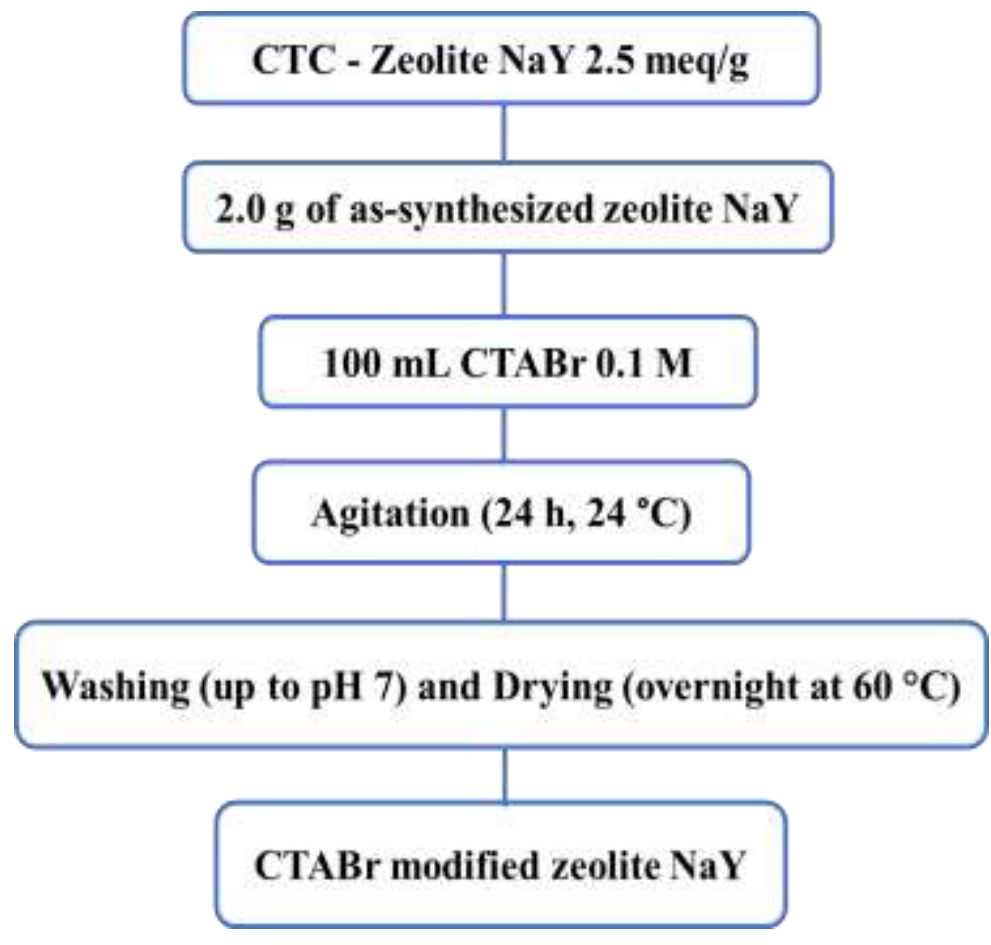

Source: Authors.

\subsection{Characterization}

\subsubsection{X-rays diffraction (XRD)}

For the characterization of samples synthesized by XRD (X-rays diffraction), a Shimadzu XRD-6000 diffractometer with $\mathrm{CuK} \alpha$ radiation was used. voltage of $40 \mathrm{KV}$, a current of $30 \mathrm{~mA}$, a step size of 0.020 and a time per step of 0.60 seconds, with a sweep speed of $2^{\circ}$ per minute and a $2 \theta$ angle ranging from $3^{\circ}$ to $50^{\circ}$.

\subsubsection{Infrared spectroscopy (IR)}

For to obtain the infrared, the IR MAGNA 560 ESPS Nicolet equipment was used. The samples in the form of tablets were previously oven dried and placed in the sample holder. IR spectra were obtained at wavelengths in the range $400-4000 \mathrm{~cm}^{-1}$ with a $4 \mathrm{~cm}^{-1}$ resolution.

\subsubsection{Thermogravimetry (TG)}

Thermogravimetric analysis was performed in a TGA/SDTA 851 equipment in a nitrogen atmosphere with a gas flow of $250 \mathrm{~mL} \cdot \mathrm{min}^{-1}$. The sample was heated from room temperature up to $900{ }^{\circ} \mathrm{C}$, at a heating rate of $10{ }^{\circ} \mathrm{C} \cdot \mathrm{min}^{-1}$.

\subsection{Batch adsorption}

Dye adsorption kinetic was determined from batch experiments with constant stirring (Tien, 1994). 
The tests started with a solution of $1000 \mathrm{mg} \cdot \mathrm{L}^{-1}$ of the dyes, from which dilutions were made, whose absorbances were analyzed in a spectrophotometric device to obtain the calibration curve.

The adsorbed quantity of dye was calculated using the following equations (Wu et al., 2009):

$$
\begin{aligned}
& \% \operatorname{Rem}=\left(\frac{\mathrm{Ci}-\mathrm{Cf}}{\mathrm{Ci}}\right) * 100 \\
& \mathrm{q}_{\mathrm{e}}=\frac{\mathrm{V}}{\mathrm{m}}(\mathrm{Ci}-\mathrm{Cf})
\end{aligned}
$$

Where: $\%$ Rem $=$ Removal percentage and $\mathrm{q}_{\mathrm{e}}=$ Adsorption capacity $(\mathrm{mg}$ dye/g zeolite $) ; \mathrm{C}_{\mathrm{i}}=$ Initial concentration $\left(\mathrm{mg} . \mathrm{L}^{-1}\right) ; \mathrm{C}_{\mathrm{f}}=$ Final concentration $\left(\mathrm{mg} \cdot \mathrm{L}^{-1}\right) ; \mathrm{V}=$ Volume of solution $(\mathrm{L}) ; \mathrm{m}=$ mass of zeolite $(\mathrm{g})$.

\subsection{Influence of pH}

The adsorption of reactive yellow BF-3R dye solution over varying $\mathrm{pH}$ (from 1.0 to 14.0) was studied under the following experimental conditions: reactive yellow BF-3R dye with an initial concentration ( $50 \mathrm{mg} / \mathrm{L})$; zeolite $(0.5 \mathrm{~g}) ; 200 \mathrm{rpm}$ stirring at 25 ${ }^{\circ} \mathrm{C}$ and $120 \mathrm{~min}$.

\subsection{Adsorption kinetics}

Reactive yellow BF-3R dye adsorption kinetics were acquired in batch experiments.

Based on reports from the reviewed literature, the ideal temperature for adsorption of dye is room temperature (Barbosa et al., 2019). Most authors reported a time of 1-3 h for adsorption process in the laboratory (Paula, Paula, \& Rodrigues, 2020; Barbosa et al., 2019).

These experiments were performed at room temperature using a solution of $50 \mathrm{mg} . \mathrm{L}^{-1}$ of reactive yellow BF-3R dye, which was put in contact with $0.5 \mathrm{~g}$ of zeolite. Adsorption experiments were conducted in erlenmeyer flasks at controlled $\mathrm{pH} 1$ for zeolite $\mathrm{NaY}$ and $\mathrm{pH} 8$ for CTABr modified zeolite $\mathrm{NaY}$ and under mechanical stirring at $200 \mathrm{rpm}$ (Certomat MO). Aliquots from the solution were collected at different time intervals between 0 and $180 \mathrm{~min}$. Afterward, the solutions were filtered and analyzed for residual reactive yellow BF-3R dye concentration with a UV-VIS 1600 (Pro-Analysis) absorption spectrophotometer in the region of ultraviolet-visible.

\section{Results and discussion}

\subsection{X-ray diffraction (XRD)}

The diffractograms of as-synthesized zeolite NaY and CTABr modified zeolite NaY are shown in Figures 3 and 4. 
Figure 3. XRD pattern of as-synthesized zeolite NaY.

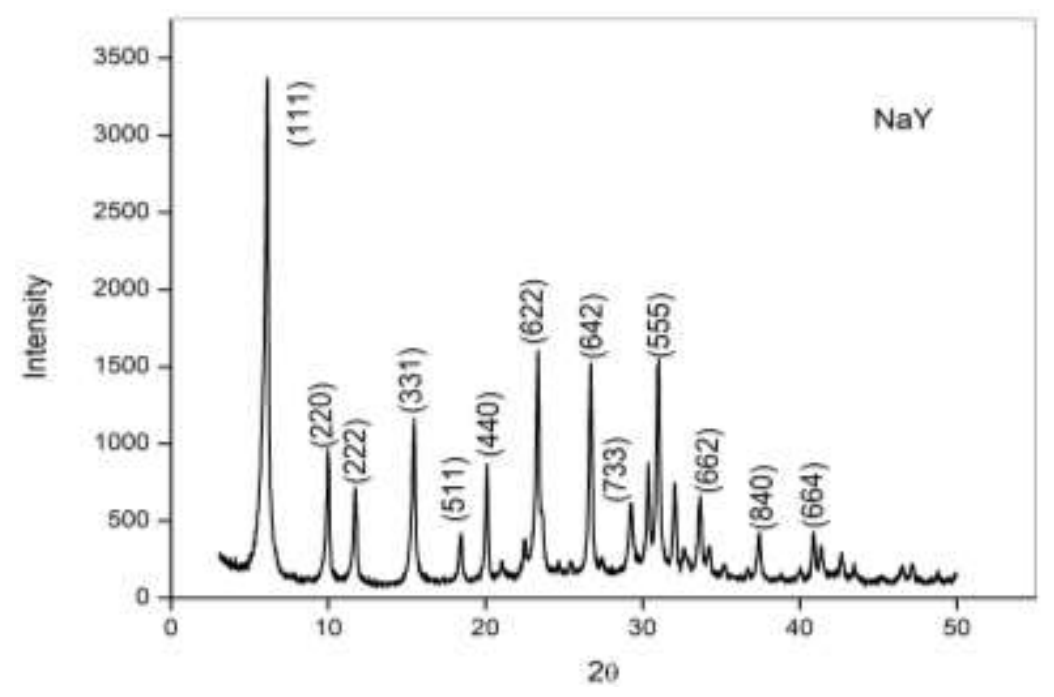

Source: Authors.

The NaY zeolite synthesized shown in Figure 3 showed well-defined and narrow peaks indicating that the zeolites obtained are characterized by high crystallinity and purity characteristic of the structure of this aluminosilicate in the range of $2 \theta=$ 5 to $50^{\circ}$, according to with the standard catalog card JCPDS 43-0168. This result agrees with the literature (Dabbawala et al., 2018).

Figure 4. X-ray diffraction pattern of the CTABr modified zeolite NaY.

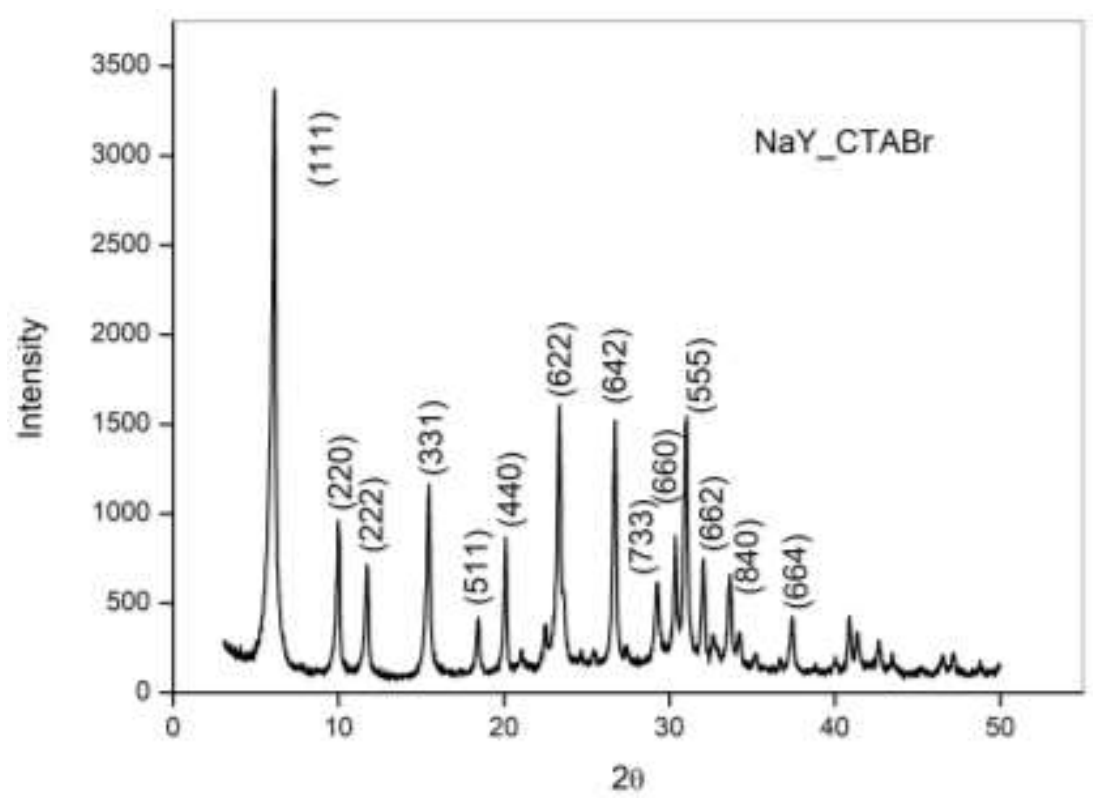

Source: Authors.

According to Figure 4, the XRD patterns of the CTABr modified zeolite NaY did not change, that is, the modification process did not change the structure of the $\mathrm{NaY}$ zeolite, maintaining its crystallinity due to its non-alteration of the $\mathrm{Si} / \mathrm{Al}$ ratio (Lutz, 2014; Mirzaei et al., 2016; Hashemi, Eslami, \& Karimzadeh, 2019). The peak intensity remained at, suggesting that the surfactant (CTABr) was adsorbed in the inner region of the zeolite NaY (Pukcothanung, Siritanon, \& Rangsriwatananon, 2018). These results are similar using the mordenite zeolite and the ZSM-5 zeolite reported in the literature (Silva et al., 2019). 


\subsection{Infrared spectroscopy (IR)}

The IR Spectroscopy of the as-synthesized zeolite NaY and CTABr modified zeolite NaY- which are given in Figure 5 and Figure 6.

Figure 5. IR spectra of as-synthesized zeolite NaY.



Source: Authors.

Figure 5 illustrates typical infrared spectra of as-synthesized zeolite NaY. It is possible to observe the characteristic bands of the structure of this aluminosilicate that is found in the region of $1100-450 \mathrm{~cm}^{-1}$ corresponding to the $\mathrm{Si}-\mathrm{O}$ and $\mathrm{Al}-\mathrm{O}$ groups. The primary $\mathrm{TO}_{4}$ units are combined in different ways to form different types of polyhedra and consequently different structures. The band in the region of $1100-1000 \mathrm{~cm}^{-1}$ is attributed to the internal vibrations of asymmetrical stretching of the $\mathrm{T}(\mathrm{Si}-\mathrm{Al})-\mathrm{O}$ bonds and the band in the region between 500 and $700 \mathrm{~cm}^{-1}$ is attributed to the symmetrical narrowing of the external tetrahedrons of the zeolite Y T-O (Taufiqurrahmi, Mohamed, \& Bhatia, 2011; Oliveira et al., 2014; Huo, 2013). The band at $1600 \mathrm{~cm}^{-1}$ refers to the angular deformation of the hydroxyl group at $3400 \mathrm{~cm}^{-1}$ corresponding to the hydroxyl groups $\mathrm{OH}$ from the water molecules present in their cavities (Kulprathipanja, 2010). 
Figure 6. IR spectra of CTABr modified zeolite NaY.

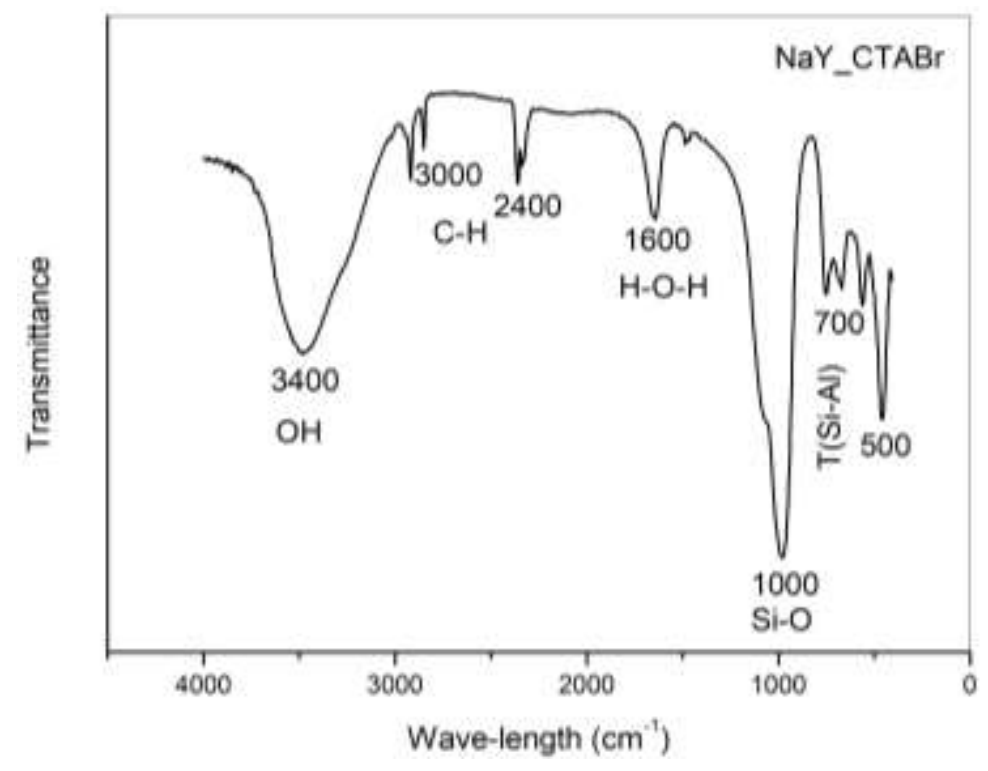

Source: Authors.

It can be observed that after modification of the zeolite $\mathrm{NaY}$ with the $\mathrm{CTABr}$, changes occur (Figure 6). The bands in the $2400-3000 \mathrm{~cm}^{-1}$ region arise from the symmetric and asymmetric elongation of $\mathrm{C}-\mathrm{H}$ belonging to the surfactant, indicating that the modification with CTABr was efficient. (Pukcothanung, Siritanon, \& Rangsriwatananon, 2018). The main characteristic bands of zeolite were maintained in the range of 480 to $1000 \mathrm{~cm}^{-1}$ which are associated with Si-O and Al-O vibrations. The band referring to the hydroxyl group was maintained in the region of $3400 \mathrm{~cm}^{-1}$, showing that the structures of zeolites are stable after modification (Lin, \& Zhan, 2012).

\subsection{Thermogravimety (TG)}

The thermogravimetric analysis of the as-synthesized zeolite $\mathrm{NaY}$ and $\mathrm{CTABr}$ modified zeolite NaY are shown in Figures 7 and 8 , respectively.

Figure 7. TG curve of as-synthesized zeolite NaY.

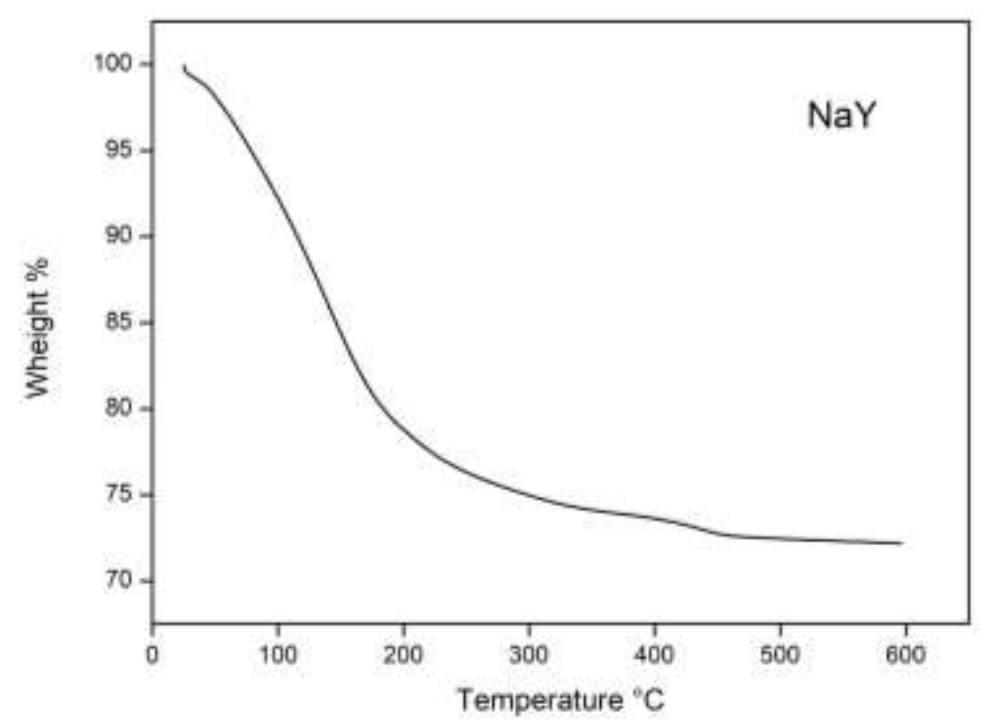

Source: Authors. 
From the thermogravimetric curves of the samples of the as-synthesized zeolite $\mathrm{NaY}$ represented in Figure 7, that the most accentuated loss of mass is observed between approximately 25 and $250{ }^{\circ} \mathrm{C}$, corresponding to $21.53 \%$, which corresponds to the elimination of physiosorbed water from the pores and the dehydration of sodium cations. The rest of the water present in the zeolites' cavities is gradually eliminated with the increase in temperature, resulting in gradual dehydration. The total mass loss for as-synthesized zeolite $\mathrm{NaY}$ was $25.09 \%$, from $400{ }^{\circ} \mathrm{C}$ onwards, no significant mass loss is observed. These results are like those found in the literature for NaY zeolites by other authors (Raharjo et al., 2019; Liu et al., 2003).

Figure 8. TG curve of CTABr modified zeolite NaY.

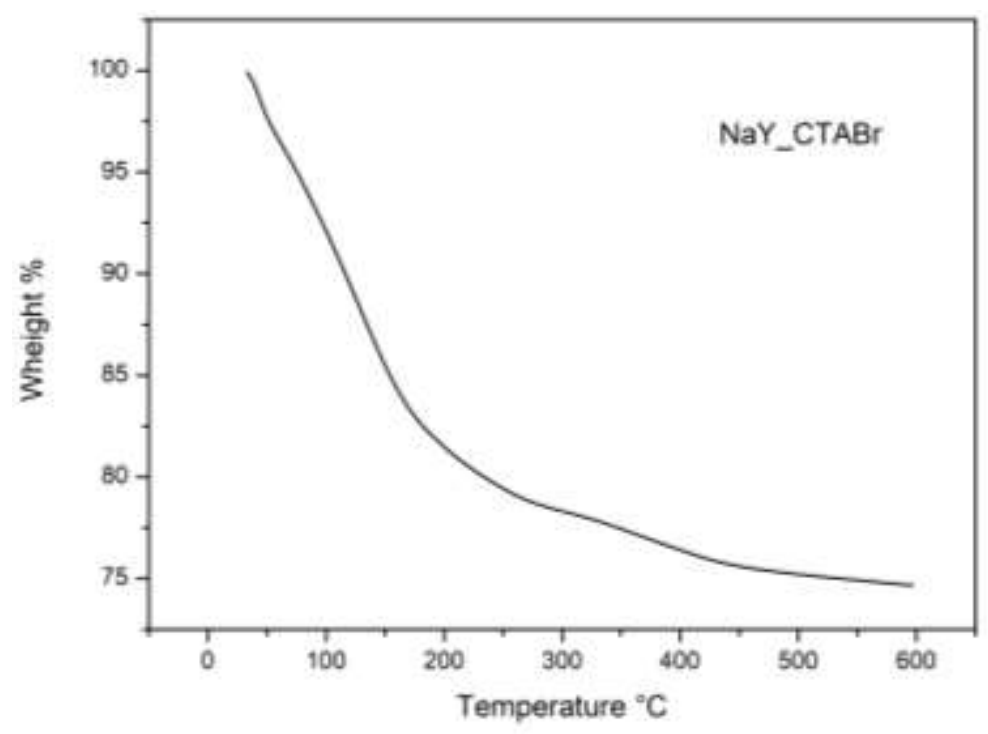

Source: Authors.

The thermogravimetric curve of the $\mathrm{CTABr}$ modified zeolite NaY (Figure 8) indicate a greater loss of mass regarding the desorption of water molecules adsorbed inside the structure of the materials up to a temperature of approximately $200{ }^{\circ} \mathrm{C}$, which corresponds to $22.07 \%$, in the sequence, a second mass loss process related to the thermal decomposition of the CTABr surfactant, which occurs between 230 and $500{ }^{\circ} \mathrm{C}$, was observed. After a temperature of $500{ }^{\circ} \mathrm{C}$ there is no significant mass loss, resulting in a total mass loss of $26.07 \%$. These results agree with those found in the literature by other researchers (Pukcothanung, Siritanon, \& Rangsriwatananon, 2018).

\subsection{Influence of pH}

Table 2 shows the values of total removal percentage of reactive yellow BF-3R dye (\% Rem) and adsorption capacity ( $\mathrm{q}_{\mathrm{e}}$ ) of as-synthesized zeolite $\mathrm{NaY}$ and $\mathrm{CTABr}$ modified zeolite $\mathrm{NaY}$. 
Table 2. Effect of $\mathrm{pH}$ on the adsorption of reactive yellow BF-3R dye in samples.

\begin{tabular}{|c|c|c|c|c|}
\hline \multirow[b]{2}{*}{ pH } & \multicolumn{2}{|c|}{ as-synthesized zeolite $\mathrm{NaY}$} & \multicolumn{2}{|c|}{ CTABr modified zeolite NaY } \\
\hline & \% Rem & $q_{e}\left(m_{g} \cdot g^{-1}\right)$ & $\%$ Rem & $\mathrm{qe}_{\mathrm{e}}\left(\mathrm{mg} \mathrm{g}^{-1}\right)$ \\
\hline 1 & 61.1060 & 3.35 & 83.0147 & 4.52 \\
\hline 2 & 45.5557 & 2.50 & 93.7316 & 5.10 \\
\hline 3 & 46.3405 & 2.54 & 95.9007 & 5.22 \\
\hline 4 & 43.9496 & 2.41 & 97.7297 & 5.32 \\
\hline 5 & 45.8934 & 2.51 & 96.4981 & 5.25 \\
\hline 6 & 42.4895 & 2.33 & 97.8492 & 5.32 \\
\hline 7 & 44.3237 & 2.43 & 97.9503 & 5.33 \\
\hline 8 & 43.4842 & 2.38 & 98.3915 & 5.35 \\
\hline 9 & 43.3838 & 2.38 & 96.0937 & 5.23 \\
\hline 10 & 44.8713 & 2.46 & 97.6378 & 5.31 \\
\hline 11 & 42.4256 & 2.32 & 97.7022 & 5.32 \\
\hline 12 & 41.6134 & 2.28 & 97.1966 & 5.29 \\
\hline 13 & 49.6167 & 2.72 & 84.0165 & 4.57 \\
\hline 14 & 24.7490 & 1.36 & 53.8786 & 2.93 \\
\hline
\end{tabular}

Source: Authors.

As shown in Table 1, the process showed low removal at basic $\mathrm{pH}$ for NaY zeolite without modification due to the properties of the adsorbent. as the $\mathrm{pH}$ value decreases. the removal percentage increases and consequently the adsorption capacity also increased. Changing the $\mathrm{pH}$ not only transforms the surface properties of the adsorbent. but also influences the existing shape of the adsorbent in the solution. changing both physical and chemical properties (Hayes, Leckie, \& 1987). The process using CTABr-modified zeolite showed an excellent percentage of removal. where we can observe a significant removal at all pH. coming from two distinct regions in the same structure. a positive hydrophilic part that results in the occupation of only one location and has a tail length of hydrophobic hydrocarbon that helps to adsorb organic molecules in aqueous solution. which increases the interaction with effluents containing dyes (Salim, \& Malek, 2016).

\subsection{Adsorption Kinetics}

The plots of $\mathrm{q}_{\mathrm{e}}$ as a function of time at the initial reactive yellow dye BF-3R concentration are presented in Figure 9. 
Figure 9. Reactive yellow BF-3R dye adsorption kinetics for samples.

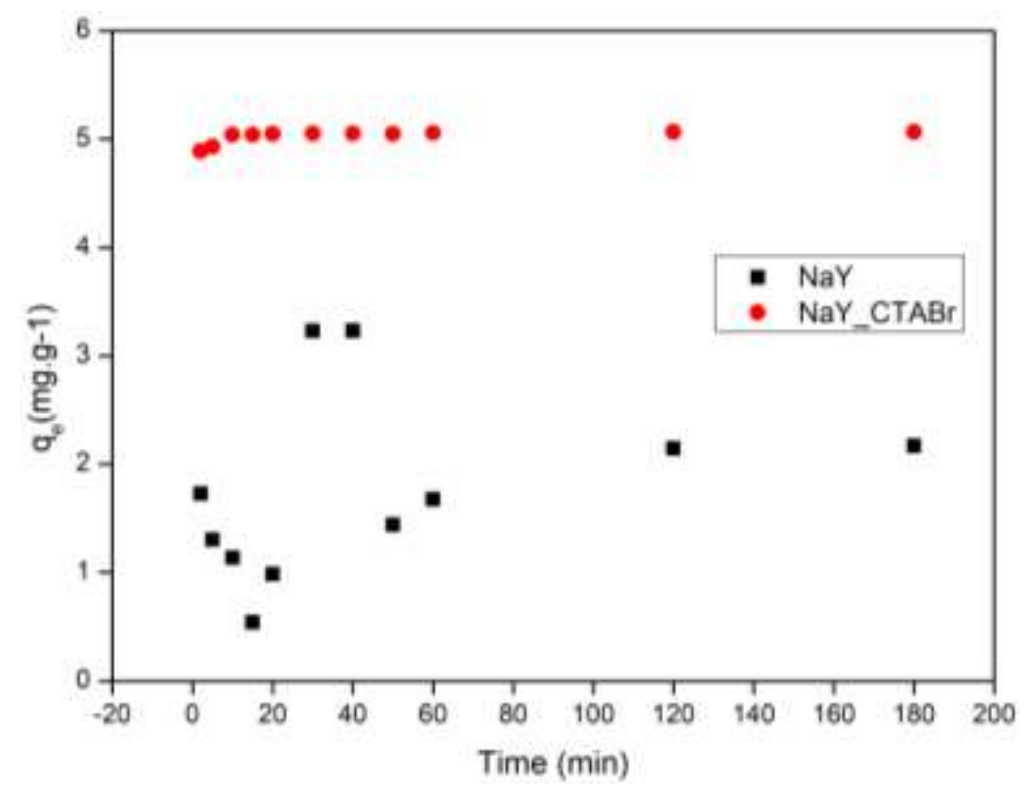

Source: Authors.

Adsorption kinetics is mainly applied to portray the rate of adsorption between adsorbate by the adsorbent. In these experiments. since the experience time between the adsorbent and the adsorbate is quite short. it is necessary to consider the time and rate of adsorption necessary for the adsorption to reach equilibrium (Zou, Shi, \& Deng. 2017; Cao et al., 2014). In Figure 7 it is possible to observe that equilibrium is reached after 2 hours for both materials. corresponding to $61.10 \%$ removal for assynthesized zeolite $\mathrm{NaY}$ and for CTABr modified zeolite NaY $98.39 \%$ removal of the yellow dye BF-3R.

\section{Conclusions}

In this work, zeolite $\mathrm{NaY}$ was synthesized from hydrothermal treatment, for the first time. Then, it was modified by $\mathrm{CTABr}$ surfactant (based on CEC of the synthetic zeolite $\mathrm{NaY}$ ) in order to remove organic dye from wastewater.

The results indicated that the zeolite $\mathrm{NaY}$ and the modification process with the surfactant cetyltrimethylammonium bromide (CTABr) did not compromise the structure of the zeolite for adsorption of the yellow dye BF-3R.

The effect of process parameter such as $\mathrm{pH}$ was studied. The results of the adsorption tests showed a maximum value of adsorption capacity in acid medium for the synthesized zeolite $\mathrm{NaY}$ adsorbent, and for the CTABr-modified NaY zeolite the best results were found in the studied $\mathrm{pH}$ range, with greater removal. in the basic medium.

Finally, this study showed that dye removal zeolite capacity can be substantially improved by modifying its surface, with $\mathrm{CTABr}$ surfactant. According to the results obtained in this work, modified zeolite is an effective sorbent for the removal of yellow dye BF-3R from aqueous solutions.

The present study represents the development of suitable strategies to prepare zeolite with surfactant for current application in the removal of dyes, as well as future applications in the release of drugs.

\section{Acknowledgements}

The authors thank the CNPq (Conselho Nacional de Desenvolvimento e Tecnológico) and CAPES (Coordenação de Aperfeiçoamento de Pessoal de Nível Superior) for their financial support. 


\section{References}

Ahmad, M. A, \& Rahman, N. K. (2011). Equilibrium, kinetics and thermodynamic of Remazol Brilliant Orange 3R dye adsorption on coffee husk-based activated carbon. Chemical Engineering Journal, 170, 154-161. https://doi.org/10.1016/j.cej.2011.03.045

Azzopardi, E. A., Owens, S. E., Murison, M., Rees, D., Sawhney, M. A., Francis, L. W., Teixeira. R. S. R., Clement. M., Conlan, R. S., \& Whitaker, I. S. (2017). Chromophores in operative surgery: Current practice and rationalized development. Journal of Controlled Release, 249, 123-130. https://doi.org/10.1016/j.jconrel.2016.12.044

Barbosa, A. S., Monteiro, G. S., Rocha, L. N., Lima, E. G.; \& Rodrigues, M. G. F. (2019). Remoção do Corante Reativo vermelho por adsorção utilizando argilas branca e vermelha. Revista Gestão \& Sustentabilidade Ambiental, 8, 539-661.

Barbosa, A. S., Rocha, L. N., Barbosa, A. S., Monteiro, G. S., \& Rodrigues, M. G. F. (2015). Argila vermelha utilizada como adsorvente na remoção de corantes reativos. In $59^{\circ}$ Congresso Brasileiro de Cerâmica.

Barbosa, T. L. A., Rodrigues, D. P. A., \& Rodrigues, M. G. F. (2019). Síntese da estrutura metalorgânica ZIF-67 e aplicação na remoção do corante Rodamina B. In XXI Congreso Argentino de Catálisis e X Congreso de Catálisis del Mercosur.

Barbosa, T. L. A., Rodrigues, D. P. A., \& Rodrigues, M. G. F. (2019). Síntese da estrutura metalorgânica ZIF-67 e aplicação na remoção do corante rodamina B. In XXI Congreso Argentino de Catálisis.

Benkhaya, S., Rabet, S. M., \& Harfi, A. E. (2020). A review on classifications, recent synthesis, and applications of textile dyes. Inorganic Chemistry Communications, 115, 107891. https://doi.org/10.1016/j.inoche.2020.107891

Cao, J., Wu, Y., Jin, Y., Yilihan, P., Huang, W. (2014). Response surface methodology approach for optimization of the removal of chromium (VI) by NH 2 -MCM41. Journal of the Taiwan Institute of Chemical Engineers, 45, 860-868. https://doi.org/10.1016/j.inoche.2020.107891

Cooney, D. O. (1999). Adsorption Design for Wastewater Treatment. Florida: CRC Press.

Dabbawala, A. A., Tzitzios, V., Sunny, K., Polychronopoulou, K., Basina, G., Ismail, I., Pillai, V., Tharalekshmy, A., Stephen, S., \& Alhassan, S. M. (2018). Synthesis of nanoporous zeolite-Y and zeolite-Y/GO nanocomposite using polyelectrolyte functionalized graphene oxide. Surface and Coatings Technology, 350, 369-375. https://doi.org/10.1016/j.surfcoat.2018.07.036

Fungaro, D. A., Bruno, M., Grosche, L. C. (2009). Adsorption and kinetic studies of methylene blue on zeolite synthesized from fly ash. Desalination and Water Treatment, 2, 231-239.

Hashemi, M. S. H., Eslami, F., \& Karimzadeh. R. (2019). Organic contaminants removal from industrial wastewater by CTAB treated synthetic zeolite Y. Journal of Environmental Management, 233, 785-792. https://doi.org/10.1016/j.jenvman.2018.10.003

Hayes, K.F., \& Leckie J. (1987). Modeling ionic strength effects on cation adsorption at hydrous oxide/solution interfaces. Journal of Colloid and Interface Science, 115, 564-572. https://doi.org/10.1016/0021-9797(87)90078-6

Huo, Z., Xu. X., Lv, Z., Song, J., He, M., Li, Z., Wang, Q., Yan, L., Li, Y. (2013). Thermal study of NaP zeolite with diferent morphologies. Journal of Thermal Analysis and Calorimetry, 111, 365-369. http://dx.doi.org/10.1007/s10973-012-2301-y

Johnson, E.B.G, \& Arshad, S.E. (2014). Hydrothermally synthesized zeolites based on kaolinite: a review. Applied Clay Science, 97-98, 215-221. https://doi.org/10.1016/j.clay.2014.06.005

Jose, M., Sriram, K., Reshma, R., Vidya, U. V., \& Shukla, S. (2018). Synergistic persulfate activation as an efficient and cost-effective approach for removal of organic synthetic-dyes from aqueous solutions using magnetic Pd - Fe3O4-fly ash composite particles as catalyst. Journal of Environmental Chemical Engineering, 6, 3709-3717. https://doi.org/10.1016/j.jece.2016.12.027

Kabra, A.N. (2011). Differential fate of metabolism of a sulfonated azo dye Remazol Orange 3R by plants Aster amellus Linn., Glandularia pulchella (Sweet) Tronc. and their consortium. Journal of Hazardous Materials, 190, 424-431. https://doi.org/10.1016/j.jhazmat.2011.03.065

Khaleque, A, Alam, M. M., Hoque, M., Mondal, S., Haider, J. B., Xu, B., Johir, M. A.H., Karmakar, A. K., Zhou, J. L., Ahmed. M. B., \& Moni, M. A. (2020). Zeolite synthesis from low-cost materials and environmental applications: A review. Environmental Advances. 2 , 100019. https://doi.org/10.1016/j.envadv.2020.100019

Kulprathipanja, S. (2010). Zeolites in Industrial Separation and Catalysis. Germany: Wiley-VCH.

Laurent, A. D., Wathelet, V., Bouhy, M., Jacquemin, D., \& Perpéte, E. (2010). Simulation de la perception des couleurs de colorants organiques. Techniques de L'ingénieur, 3-4, 6810.

Lima, L. A., Mota, M. F., Menezes, V. M. R., \& Rodrigues, M. G. F. (2014). Síntese da peneira molecular MCM-41 e sua utilização como adsorvente na remoção do corante azul reativo BF-5G. In XX Congresso Brasileiro de Engenharia Química.

Lima, L. A., Paula, G. M., \& Rodrigues, M. G. F. (2014). Síntese da peneira molecular SBA-15 e sua utilização como adsorvente na remoção de corantes. In XXIV Congresso Iberoamericando de Catálisis.

Lin, J., \& Zhan, Y. (2012). Adsorption of humic acid from aqueous solution onto unmodified and surfactant-modified chitosan/zeolite composites. Chemical Engineering Journal, 200-202, 202-213. https://doi.org/10.1016/j.cej.2012.06.039

Liu, X., Yan, Z., Wang, H., \& Luo, Y. (2003). In situ synthesis of NaY zeolite with coal-based kaolin. Journal of Natural Gas Chemistry, 12 , 63 - 70.

Lo, B. T. W, Ye, L., \& Tsang. S. C. E. (2018). The Contribution of Synchrotron X-Ray Powder Diffraction to Modern Zeolite Applications: A Mini-review and Prospects. Chemistry, 4, 1778-1808. 
Lutz, W. (2014). Zeolite Y: synthesis, modification, and properties - a case revisited. Advances in Materials Science and Engineering, 13,1 - 20.

Ma. T., Wu, Y., Liu, N., \& Wu, Y. (2020). Hydrolyzed polyacrylamide modified diatomite waste as a novel adsorbent for organic dye removal: Adsorption performance and mechanism studies. Polyhedron, 175, 114227. https://doi.org/10.1016/j.poly.2019.114227

Mirzaei, N., Hadi, M., Gholami, M., Fard, R.F., \& Aminabad, M.S. (2016). Sorption of acid dye by surfactant modificated natural zeolites. Journal of the Taiwan Institute of Chemical Engineers, 59, 186 - 94. http://dx.doi.org/10.1016\%2Fj.jtice.2015.07.010

Ngulube, T., Gumbo, J. R., Masindi, V., \& Maity, A. (2017). An update on synthetic dyes adsorption onto clay-based minerals: A state-of-art review. Journal of Environmental Management,191, 35-57. https://doi.org/10.1016/j.jenvman.2016.12.031

Nogueira, A. C., Barbosa, T. S. B., Barros, T. R. B., \& Rodrigues, M. G. F. (2020). Caracterização e aplicação de argilas vermiculita e esmectita (verde lodo) na adsorção de corantes na indústria têxtil. In Pesquisas Multidisciplinares em Ciências Exatas (pp. 369-379). http//doi/10.47402/ed.ep.c202150825966

Nupearachchi, C.N., Mahatantila. K., \& Vithanage, M. (2017). Application of graphene for decontamination of water; implications for sorptive removal. Groundwater for Sustainable Development, 5, 206 - 215. https://doi.org/10.1016/j.gsd.2017.06.006

Oliveira, L. A., Araújo, I. N., Cunha, R. S. S., Mota, J. D. \& Rodrigues, M. G. F. (2020). Planejamento experimental da remoção de corante amarelo reativo através de argila esmectita. In Processos Químicos e Biotecnológicos (pp. 104-115). http//doi/10.36229/978-65-5866-009-5.CAP.11

Oliveira, T.G. (2014). Adsorção de CO2 em peneiras moleculares micro e mesoporosas. Química Nova, 37, 610-614.

Paula, L. N. R., Paula, G. M., \& Rodrigues, M. G. F. (2020). Adsorption of reactive blue BF-5G dye on MCM-41 synthesized from chocolate clay. Cerâmica, 66, 269-276. http://dx.doi.org/10.1590/0366-69132020663792862

Pukcothanung, Y., Siritanon, T., \& Rangsriwatananon, K. (2018). The efficiency of zeolite Y and surfactant-modified zeolite Y for removal of 2,4dichlorophenoxyacetic acid and 1,1'-dimethyl-4,4'-bipyridinium ion. Microporous and Mesoporous Materials, 258, 131-140. https://doi.org/10.1016/j.micromeso.2017.08.035

Radoor, S., Karayil, J., Jayakumar, A., Parameswaranpillai, J., \& Siengchin, S. (2021). Efficient removal of methyl orange from aqueous solution using mesoporous ZSM-5 zeolite: Synthesis. kinetics. and isotherm studies. Colloids and Surfaces A: Physicochemical and Engineering Aspects, 611, 125852. https://doi.org/10.1016/j.colsurfa.2020.125852

Radoor, S., Karayil, J., Parameswaranpillai, J., Siengchin, T. (2020). Adsorption Study of Anionic Dye, Eriochrome Black T from Aqueous Medium Using Polyvinyl Alcohol/Starch/ZSM-5 Zeolite Membrane. Journal of Polymers, and the Environment, 28, 2631-2643. https://doi.org/10.1007/s10924-020-01812-w

Raharjo, Y., Ismail, A. F., Othman, M. H. D., Malek, N. A. N. N., \& Santoso. D. (2019). Preparation and characterization of imprinted zeolite-Y for p-cresol removal in haemodialysis. Materials Science and Engineering: C, 103, 109722. https://doi.org/10.1016/j.msec.2019.05.007

Rocha, L. N., Barbosa, A. S., \& Rodrigues, M. G. F. (2016). Ensaio de adsorção de dois corantes reativos utilizando argila vermelha. In XXI Congresso Brasileiro de Engenharia Química.

Rocha, L. N., Barbosa, A. S., \& Rodrigues, M. G. F. (2016). Remoção do corante vermelho BF-4B em sistema descontínuo utilizando argilas esmectíticas. In XI Encontro Brasileiro sobre Adsorção.

Rocha, L. N., Barbosa, A. S., Monteiro, G. S., \& Rodrigues, M. G. F. (2017). Estudo de adsorção de corantes reativos utilizando argila vermelha. In 61 ${ }^{\circ}$ Congresso Brasileiro de Cerâmica.

Rocha, L. N., Barbosa, A. S., Monteiro, G. S., \& Rodrigues, M. G. F. (2017). Cinética de adsorção de corantes utilizando a argila Branca como adsorvente. In 19 Congresso Brasileiro de Catálise.

Rocha, L. N., Barbosa, A. S., Monteiro, G. S., Barbosa, A. S., \& Rodrigues, M. G. F. (2015). Influência do pH na remoção de corantes reativos utilizando argilas como adsorventes. In $18^{\circ}$ Congresso Brasileiro de Catálise.

Rodrigues, D. P. A., Barbosa, T. L. A., \& Rodrigues, M. G. F. (2020). Zeolitic Imidazolate Framework-8 Nanoparticles for Rhodamine B Adsorption. Current Nanomaterials, 6, 1- 8. https://doi.org/10.2174/2468187310999201120091142

Rodrigues, D. P. A., Barbosa, T. L. A., \& Rodrigues, M. G. F. (2020). Adsorção de Rodamina B em ZIF-8 e ZIF-67: Efeito nas estruturas. In Engenharia no Século XXI (pp. 16-29). http//doi/10.36229/978-65-86127-45-4.CAP.03

Ruthven, D. M. (1984). Principles of Adsorption and Adsorption Process. John Wiley \& Sons, 5, 7-18.

Salim, M.M., \& Malek, N.A.N.N. (2016). Characterization and antibacterial activity of silver exchanged regenerated NaY zeolite from surfactant-modified NaY zeolite. Materials Science and Engineering: C, 59, 70-77. https://doi.org/10.1016/j.apsusc.2018.05.222

Silva, E. T. dos S., Rodrigues, D. P. A., Tomaz, P. F., Barbosa, T. L. A., \& Rodrigues, M. G. F. (2019). Preparação de estrutura metalorgânica ZIF-8: Aplicação em adsorção de Rodamina B. In $63^{\circ}$ Congresso Brasileiro de Cerâmica.

Silva, F. M. N., Barbosa, A. S., Cunha, R. S. S., \& Rodrigues, M. G. F. (2020). Preparação e caracterização de membrana inorgânica com propriedades para remoção de corante amarelo reativo BF - 3R. In Processos Químicos e Biotecnológicos (pp. 93-103). http//doi/10.36229/978-65-5866-009-5.CAP.10

Silva, F. M. N., Silva, L. R. B., Silva, E. T. S., \& Rodrigues, M. G. F. (2019). Síntese da zeólita mordenita e modificação com CTMABr. Aplicação na remoção do corante Rodamina B. In XXI Congreso Argentino de Catálisis.

Silva, F. N. M.; Barbosa, T. L. A.; D. P. A.; \& Rodrigues, M. G. F. (2019). Síntese da zeólita SAPO-34 e aplicação na remoção do corante reativo amarelo BF3R. In XXI Congreso Argentino de Catálisis. 
Research, Society and Development, v. 10, n. 14, e323101422147, 2021

(CC BY 4.0) | ISSN 2525-3409 | DOI: http://dx.doi.org/10.33448/rsd-v10i14.22147

Silva, L. R. B., Barbosa, T. L. A., Bezerra, J. U. L., \& Rodrigues, M. G. F. (2020). Síntese da Zéolita ZSM-5 para ser utilizada como adsorvente na remoção do corante reativo BF-3R: influência do pH. In Processos Químicos e Biotecnológicos (pp. 66-78) http//doi/10.36229/978-65-86127-43-0.CAP.09

Silva, L. R. B., Barbosa, T. L. A., Bezerra, J. U. L., \& Rodrigues, M. G. F. (2019). Zeólita ZSM-5 não modificada e modificada com surfactante CTMABr: aplicação na remoção do corante amarelo BF-3R. In $63^{\circ}$ Congresso Brasileiro de Cerâmica.

Silva, L. R. B., Rodrigues, M. G. F., do Carmo. E. S., Barbosa. A. S., \& Silva. E. T. (2019). Unmodified ZSM-5 zeolite with CTMABr surfactant: application to remove BF-3R yellow dye. In $63^{\circ}$ Congresso Brasileiro de Cerâmica.

Sivalingam, S, \& Sen, S. (2018). Optimization of synthesis parameters and characterization of coal fly ash derived microporous zeolite X, Applied Surface Science, 455, 903-910. https://doi.org/10.1016/j.apsusc.2018.05.222

Taufiqurrahmi, N., Mohamed, A. R., \& Bhatia, S. (2011). Nanocrystalline zeolite Y: Synthesis and characterization. IOP Conference Series: Materials Science and Engineering, 17, 1-6.

Tien, C. (1994). Adsorption Calculation and modeling.

Tomaz, P. F., Rodrigues, D. P. A.; Barbosa, T. L. A., \& Rodrigues, M. G. F. (2019). Nova rota de síntese da estrutura metalorgânica ZIF e argila para serem utilizadas na remoção de corante rodamina B. In XXI Congreso Argentino de Catálisis.

Wanyonyi, W.C., Onyari, J.M., \& Shiundu, P.M. (2014). Adsorption of Congo red dye from aqueous solutions using roots of eichhornia crassipes: kinetic and equilibrium studies. Energy Procedia, 50, 862 - 869. https://doi.org/10.1016/j.egypro.2014.06.105

Wu, F., Tseng, R., Huang, S., Juang, R. (2009). Characteristics of pseudo-second-order kinetic model for liquid-phase adsorption: A mini-review. Chemical Engineering Journal, 151, 1-9.

Zou, Z., Shi, Z., \& Deng, L. (2017). Highly efficient removal of $\mathrm{Cu}(\mathrm{II})$ from aqueous solution using a novel magnetic EDTA functionalized $\mathrm{CoFe}_{2} \mathrm{O}_{4}$. $R S C$ Advances, $7,5195-5205$ 